\title{
The Spiritual Gospel
}

\author{
M. F. WILES
}

Mr Wiles examines the interpretation of the Fourth Gospel by the Greek fathers, especially Origen, Theodore of Mopsuestia and Cyril of Alexandria. His book adds to our understanding both of St John's Gospel itself and of the Exegesis of the great early commentators.

\section{CAMBRIDGE UNIVERSITY PRESS}

BENTLEY HOUSE, 200 EUSTON ROAD, LONDON, N.W. I

FULL PARTICULARS OF THE

\section{JOURNALS}

PUBLISHED BY THE

CAMBRIDGE

UNIVERSITY PRESS

MAY BE HAD FROM

THE MANAGER

CAMBRIDGE UNIVERSITY

PRESS

BENTLEY HOUSE

200 EUSTON ROAD

LONDON, N.W 1

\section{MAN IN COMMUNITY}

By Russell P. SHedD

This study of the meaning and implications of the Pauline doctrine of human solidarity has been prompted by current interest in the New Testament teaching about Church unity. No earlier work has treated the subject so comprehensively.

30 s. net

\section{JESUS AND THE \\ FUTURE LIFE}

By William STRAwSON

It is not true to say, as is sometimes asserted, that we can learn practically nothing about the future life from the teachings of Jesus. The author contends that there is a surprisingly large amount of material available-to witness to the undeniable reality of life hereafter.

30s. net

THE EPWORTH PRESS

25-35 City Road, London, E.C. 1 


\title{
BOOKS BY CALVIN
}

\section{Calvin's Commentaries}

\author{
A new translation edited by \\ D. W. and T. F. TORRANCE
}

The need for a fresh approach to the Commentaries which form such an important part of Calvin's work has become increasingly apparent in recent years. Professor T. F. Torrance of New College, Edinburgh, and his brother the Rev. David W. Torrance have, therefore, undertaken to edit a new translation to replace Beveridge's standard version which appeared over a hundred years ago. This new translation will be published in twelve volumes during the course of the next three years. The first two volumes, now available, are

St John I-10

translated by T. H. L. Parker, $25 s$.

\section{Corinthians}

translated by J. W. Fraser, 27s. $6 d$.

\section{Calvin's Tracts and Treatises}

\section{Introduction and Historical Notes by}

$$
\text { T. F. TORRANCE }
$$

The republication of Calvin's Tracts and Treatises makes available again a large and significant body of literature which has greatly influenced all the churches that arose out of the Reformation. Professor Torrance in his introduction remarks 'It is now apparent as we look back over the last four hundred years that to John Calvin must be ascribed the honour of being the father of modern theology. It was he who showed the way back to a positive theology grounded upon the word of God. . . P Positive theology today once more returns to Calvin for guidance and inspiration, in thinking out and expressing the authentic message of revelation'.

Three volumes $£_{5} .5$ s. Od. the set

\section{- OLIVER AND BOYD}

